\title{
Covid-19 Outbreak: How the Public Health Network Could Function Better in Disseminating Information and Instruction for Action? Lessons Learned
}

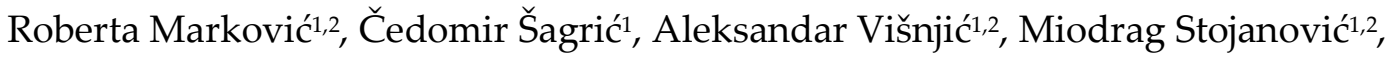 \\ Aleksandra Ignjatović1,2, Zorana Deljanin ${ }^{2}$ \\ ${ }^{1}$ University of Niš, Faculty of Medicine, Niš, Serbia \\ ${ }^{2}$ Public Health Institute Niš, Niš, Serbia
}

SUMMARY

The priority for the period of COVID-19 outbreak was to provide fast, well-timed dissemination of information to the general population (especially vulnerable groups) as well to health professionals and professionals from other areas of public life (police, army, local governments, education, and the business sector) on behavior change and prevention measures, in terms of guidance for the current epidemiological situation.

At the Public Health Institute Niš, Serbia, we directed activities relying primarily on formal intervention approaches, WHO guidance and on information and knowledge gained at the April 2019 WHO "Emergency Risk Communication training and plan-writing workshop" in Belgrade/Serbia. To define the advantages and disadvantages of the applied method for dissemination of information, we followed the reporting guidance contained in Duncan E and colleagues', Guidance for reporting intervention development studies in health research (GUIDED).

Guidelines for treatment and recommendations were disseminated through standard communication channels. A local public health network with a large number of partners from the governmental and non-governmental sector, established in recent years, was a kind of channel for dissemination of materials.

We realized that formal intervention approaches should be rapidly improved by better mapping of all population groups, by modern ways of communication, by urgent introduction of digital communication channels such as telemedicine, smart phone engagement and internet applications, in order to educate and exchange information more efficiently and quickly, especially in crisis situations such as COVID-19 epidemics/pandemics.

Key words: COVID-19, public health, education

Corresponding author:

Roberta Marković

e-mail: robertarim@yahoo.com 


\section{INTRODUCTION}

The year 2020 will be remembered for the COVID-19 outbreak, which on 30 January was declared by WHO as a public health emergency of international concern (PHEIC), and on 11 March it was characterized as a pandemic (1). The first case of COVID-19 in the Republic of Serbia was confirmed on 6 March 2020. On the same day, the WHO Director reported during a media briefing that there was "a total of 98,023 reported cases of COVID-19 globally and 3,380 deaths and recommended that all countries should make containment their highest priority" (2). As of July 2, 2020, a total of 10,834,159 confirmed cases and 519,582 deaths were reported worldwide. On the same day, a total of 14,836 confirmed cases and 281 deaths were reported in Serbia (3).

The spread rate of COVID-19 and the surprisingly high number of deaths in some countries were an alarm-bell for public health specialists worldwide to take a proactive role in raising pandemic preparedness. Therefore, it was a priority to provide fast, well-timed dissemination of information and instructions for action in the crisis situation on two levels:

A) To provide information to the general population (especially vulnerable groups) on behavior change and prevention (protection) measures;

B) To ensure the dissemination of information to all professionals involved in crisis control and resolution: health professionals, in terms of guidance for the current epidemiological situation; and professionals from other areas of public life who are actively involved in certain processes (for example police, army, local governments and their services, education, judiciary, and the business sector).

\section{AIMS}

The aims of this article were:

1. To describe the advantages and disadvantages of applied method for dissemination of information on prevention measures against COVID-19 spread to the general population.

2. To describe the advantages and disadvantages of applied method used for dissemination of guidance for treatment, algorithms and recommendations to the health and non-health professionals involved in COVID-19 crisis management.

\section{METHODS}

In this article, we described how dissemination activities were carried out during the COVID-19 spread in Serbia, draw conclusions including advantages and disadvantages of our interventions, and suggested possible improvements which we believe would improve outcomes in future scenarios. At the Public Health Institute Niš (PHI Niš), we directed activities relying primarily on formal intervention approaches, but WHO guidance (4) and information and knowledge gained at the April 2019 WHO "Emergency Risk Communication Training and Plan-Writing Workshop" (organized by WHO Serbia Country Office, in Belgrade, Serbia) also significantly influenced our management of the dissemination activities. We follow the reporting guidance contained in Duncan E and colleagues', Guidance for reporting intervention development studies in health research (GUIDED) (5), to describe our activities in this article.

\section{RESULTS}

A network of 24 Public Health Institutes, led by the National Public Health Institute and the Ministry of Health, deals with Public Health issues in Serbia. Within the network, the Public Health institute Niš, with all its organizational units (epidemiology, hygiene, microbiology, social medicine and health promotion) conducts activities in the field of Public Health in two districts in Southeast Serbia, whose total population is about 500 thousand (almost $8 \%$ of the total population of Serbia, according to last census).

With the appearance of COVID-19 in the surrounding countries, the Public Health Institute, following WHO guidance (4) activated all mechanisms to prevent the spread of COVID-19 in the districts that it is responsible for. The specific assignments described in this article was the dissemination of information about COVID-19, where the key role was played by two centers in the Institute: the Center for Health Promotion and the Center for Disease Control and Prevention.

The Center for Health Promotion rapidly started developing recommendations for behavior in the form of educational materials, brochures, posters, recommendations, as well as defining a method for disseminating the necessary information and ma- 
terials. The basis for the development of these materials were WHO recommendations (6) and guidelines, Centers for Disease Control (CDC) materials (7), European Centre for Disease Prevention and control (ECDC) materials (8) and scientific papers on the web, which were then adapted to national and local characteristics and to the knowledge of Public Health experts employed at the Institute.

The priority task was to map quickly those priority situations and groups where the spread of the epidemic could be expected. The first materials contained basic information for the general population on COVID-19 protection and symptoms. This was presented through two electronic flyers "How to protect yourself from the corona virus" and "Signs of corona virus infection" in which the phone numbers of the already established call center were also visible (accessible on PHI Nis web) (9). This was followed by several more sets of electronic instructions: "Make your home safe", "Make your workplace safe", "Make your educational institution safe", "Make commercial facilities safe", "Guidelines for public institutions", "How to protect yourself from COVID-19 in public transport", "How to make your apartment building safe from COVID-19", "How to make shops and grocery stores safe from COVID19", "How to protect yourself from COVID-19 if you are over 65 ", "How to protect yourself from COVID19 at school", "General hygiene tips", "Recommendations for people with diabetes" and "Recommendations for behavior in parks, picnic and recreational areas". Two guidelines addressed "prevention of stress and anxiety during the COVID-19 pandemic" and "How to get psychophysically empowered during a stay in home isolation" as well as "Questions and Answers".

Relying on the conclusions and experiences gathered worldwide until that moment in time, (the second week of March 2020) the known key COVID19 preventive behaviors measures were emphasized: social distancing, good personal hygiene, washing hands immediately with liquid soap in a proper way, covering nose and mouth with a tissue when sneezing or coughing, or sneezing into the elbow, mandatory wearing of facemasks in certain environments, and ventilation of offices and home.

The challenge was how to get messages out, widely and as promptly as possible, through trusted and easily reached channels. The second question was how to implement this as a community-based program in order to reach adequate society response (10). A local public health network with a large number of partners from the governmental and non-governmental sector, established in recent years, was of great help. The members of the network are not only health care institutions (primarily primary health care), but also local self-government, schools, colleges, youth organizations, social institutions, cultural institutions, sports organizations, citizens' associations, the Red Cross nongovernmental organizations (NGOs), and the media. Readily available digital communication methods such as Zoom and Skype greatly facilitated communication of information among the members of the Public Health Network, and the solving of issues as they arose.

In the week before the declaration of the state of emergency (declared on 15 March) we published all the instructions on the Public Health Institute website. In addition, all materials were sent to the network of health institutions in two districts (27 health facilities and a clinical Center with 27 clinics) with instructions to publish the materials on their websites, as well as to print it and place it at visible places.

Educational material in the form of a poster intended for elementary school pupils was created and printed within 48 hours. In the meantime, the Ministry of Education of the Republic of Serbia made a decision to close schools, which hindered the distribution of posters. We then quickly developed an alternative approach, in which we gave the poster to the School Board in electronic form, who then distributed it to a network of teachers and class presidents, who further distributed it to all pupils and teachers via a Viber network. At the same time, educational materials and behavioral recommendations were forwarded to the University of Niš, which operates 14 faculties with a current total of 24,667 students (and more than 2000 staff), recommending to make these guidelines visible and widely available to employees and students (on the University's website, via Facebook, Viber student groups, student parliaments and associations).

In order to share educational material countrywide, we offered it to the "Standing conference of towns and Municipalities" (SCTM), the major nongovernmental organization which supports the development of local governments in Serbia, for dissemination at the national level. By posting the materials of the Institute on their website for fur- 
ther distribution to local governments, we had the coverage of 200 municipalities and local governments in the entire Republic of Serbia.

The second group of activities was related to the dissemination of guidelines for treatment, algorithms and recommendations for health professionals. The Center for Disease Control and Prevention had the obligation, in addition to activities on control and containment of the epidemic, to promptly forward guidance, algorithms and instructions to health professionals in 28 health institutions in two districts of PHI responsibility.

The guidance for treatment, algorithms and recommendations defined the method of patients triage, diagnosis, testing, and therapy for the infected and defined the place and time of sending patients to quarantine or a COVID-19 hospital, as well as obligating sending to quarantine all who had contact with infected persons to home isolation. As knowledge in the field of COVID-19 was frequently updated, the epidemic management, and the guidance, algorithms, and recommendations were correspondingly updated. The model applied for forwarding guidelines for treatment, algorithms and recommendations was a) use of standard communication channels (mail, telephone, correspondence.) and $b$ ) dissemination of information intended for professionals using previously established professional networks. Using this approach meant that challenges and queries regarding the application of updated algorithms, recommendations, and instructions, were expected to be resolved by direct communication between professionals of this Center and colleagues "in the field". This way of too much personalized communication in dissemination of information has slowed down the functioning of all actors, increasing the effort needed to provide timely and effective intervention. This was recently asserted in The Lancet regarding guidance for health professionals "Guidance on how to manage patients with COVID-19 must be delivered urgently to health-care workers in the form of workshops, online teaching, smart phone engagement, and peer-to-peer education" (11) and we have recognized this as a necessity in our work. Moreover, as Tokuc B. and Varol G. emphasized in their paper "medical education is an area open to change and development, and these changes accelerate under challenging times" (12).

\section{CONCLUSIONS}

In general, the planning of public health interventions in crisis situations at the local level should be part of existing national action plans for emergency preparedness and response, which should be in compliance with WHO Emergency Risk Communication (ERC) package guidelines. This will ensure implementation of innovative tools and methods that will improve communication in crises such as the COVID-19 epidemic/pandemic. Specifically related to our experience, our conclusions are:

A. The advantages of the applied method for the general population were reflected in the rapidity of communication, the availability of all actors in the Public Health network and the large coverage of the population with educational materials and recommendations for behavior change, during the COVID19 epidemic/pandemic. A disadvantage was the absence of providers for some specific social groups in Public Health network, so there was no specific approach to the population of parents with children with autism, the elderly in the countryside, the homeless and migrants.

Our recommendations regarding limitations of presented model are: a) better mapping of insufficiently visible vulnerable groups and their inclusion in the public health network, b) constant monitoring of changes in the world of digital communication in order to make our recommendations available to all population groups through the application of new communication channels.

B. The use of standard channels of communication with health professionals (email, telephone and correspondence) did not allow the rapid dissemination of information and at the same time did not provide possibility for all dilemmas or questions from the field to be answered on time. It is recommended to introduce new digital communication channels such as telemedicine, smart phone engagement and internet applications intended for communication, in order to communicate more efficiently and effectively with health professionals, especially in crisis situations such as epidemics/pandemics. 


\section{References}

1. World Health Organization. WHO announces COVID-19 outbreak a pandemic. Available from: http://www.euro.who.int/en/health-topics/healthemergencies/coronavirus-covid19/news/news/2020/3/who-announces-covid-19outbreak-a-pandemic

2. World Health Organization. WHO DirectorGeneral's opening remarks at the media briefing on COVID-19-11 March 2020. Geneva, Switzerland. 2020 Mar.

3. Worldometer D. COVID-19 Coronavirus Pandemic. Accessed on July 02. Available from: https://www.worldometers.info/coronavirus/

4. World Health Organization. Communicating risk in public health emergencies: a WHO guideline for emergency risk communication (ERC) policy and practice. World Health Organization; 2017. Available from:

https://www.who.int/risk-

communication/guidance/download/en/

5. Duncan E, O'Cathain A, Rousseau N, et al. Guidance for reporting intervention development studies in health research (GUIDED): an evidencebased consensus study BMJ Open 2020;10:e033516. https://doi.org/10.1136/bmjopen-2019-033516
6. World Health Organization. Coronavirus disease 2019 (COVID-19): situation report, 72

7. Centres for Disease Control and Prevention. Prevent getting sick. Available from: https://www.cdc.gov/coronavirus/2019ncov/prevent-getting-sick/index.html

8. European Centre for Disease Prevention and Control. Prevention and control https://www.ecdc.europa.eu/en/publicationsdata?f\%5B0\%5D=public health areas $\% 3 \mathrm{~A} 1571$

9. Public Health Institute Niš http://www.izjz-nis.org.rs/

10. Aslan, Dilek, and İskender Sayek. "We Need to Rethink on Medical Education for Pandemic Preparedness: Lessons Learnt From COVID-19." Balkan Med J. 2020; 37(4):178-9. https://doi.org/10.4274/balkanmedj.galenos.2020.2 $\underline{020.4 .002}$

11. Lancet T. COVID-19: Too little, too late? Lancet. 2020; 395(10226):755.

12. Tokuç B, Varol G. Medical Education in Turkey in Time of COVID-19. Balkan Med J 2020;37:180-1. https://doi.org/10.4274/balkanmedj.galenos.2020.2 $\underline{020.4 .003}$ 


\title{
Izbijanje epidemije Covid-19 virusa: kako mreža javnog zdravlja može funkcionisati bolje u prosleđivanju informacija i instrukcija za akcije? - naučene lekcije
}

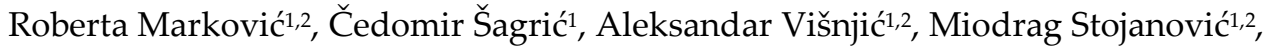 \\ Aleksandra Ignjatovićc ${ }^{1,2}$, Zorana Deljanin ${ }^{2}$ \\ ${ }^{1}$ Univerzitet u Nišu, Medicinski fakultet, Niš, Srbija \\ 2Institut za javno zdravlje Niš, Niš, Srbija
}

\section{S A ŽETAK}

Sa pojavom COVID-19 virusa prioritetno je bilo omogućiti brzo i blagovremeno širenje informacija široj populaciji (posebno osetljivim grupama), kao i zdravstvenim radnicima i profesionalcima iz oblasti javnog života (policiji, vojsci, lokalnim samoupravama, školama/fakultetima i poslovnom sektoru) o promenama ponašanja i merama prevencije.

U Institutu za javno zdravlje u Nišu, (Srbija), usmerili smo aktivnosti oslanjajući se prvenstveno na formalne pristupe intervencijama, kao i smernice SZO date kroz održanu obuku u Beogradu (RS) aprila 2019. godine - „Obuka za komunikaciju i pisanje plana u vanrednim situacijama“. Da bismo kroz ovaj rad definisali prednosti $\mathrm{i}$ nedostatke primenjene metode za širenje informacija, sledili smo smernice za izveštavanje date $u$ "Vodiču za izveštavanje o razvojnim studijama intervencija u zdravstvenim istraživanjima (GUIDED)" Duncana E i saradnika.

Smernice za lečenje i preporuke distribuirane su putem standardnih komunikacionih kanala. Lokalna mreža javnog zdravstva, sa velikim brojem partnera iz vladinog i nevladinog sektora, uspostavljena poslednjih godina, bila je neka vrsta kanala za širenje materijala.

Formalne pristupe intervencijama treba brzo poboljšati boljim mapiranjem svih grupa stanovništva, savremenim načinima komunikacije, hitnim uvođenjem digitalnih komunikacionih kanala kao što su telemedicina, angažovanje pametnih telefona i internet, kako bi razmena informacija bila efikasnija i brža, posebno u kriznim situacijama, kao što su epidemije/pandemije COVID-19 virusa.

Ključne reči: COVID-19; zdravstvo; obrazovanje 